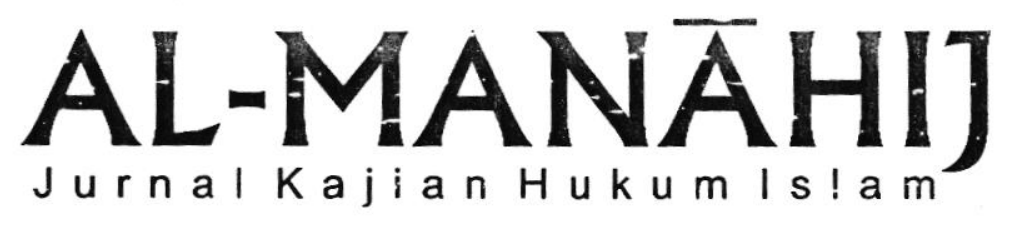




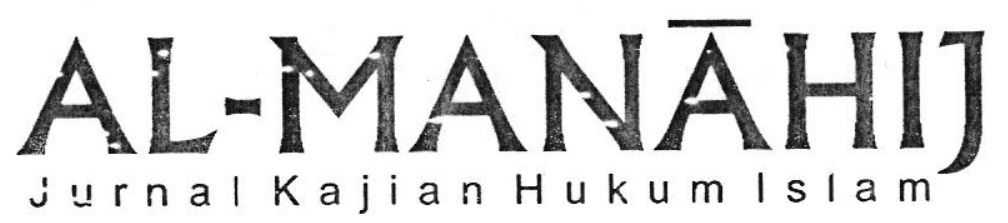

$\begin{array}{lll}\begin{array}{l}\text { Ketua Penyunting } \\ \text { Sekretaris Penyunting }\end{array} & : \text { Jamal Abdul Aziz } \\ \text { Anggota Penyunting } & : \text { H.M. Daelikhin } \\ & \begin{array}{l}\text { Ansori } \\ \text { A. Luthfi Hamidi } \\ \text { Ridwan } \\ \text { Suraji } \\ \text { Endang Widuri }\end{array} \\ & \begin{array}{l}\text { Supriyanto } \\ \text { Rina Heriyanti }\end{array} \\ \text { Editor Bahasa } & \begin{array}{l}\text { Siti Faizah Hidayati } \\ \text { Dyah Ratri Fiyani }\end{array}\end{array}$

\author{
Penerbit \\ Jurusan Syariah STAIN Purwokerto \\ Frekuensi Terbit \\ Duakalisetahun
}

Alamat Redaksi

Jurusan Syari'ah STAIN Purwokerto

J1. Jend. Ahmad Yani 40A Purwokerto 53126

Telp. (0281)635624 Fax. (0281)636553

Email: mal_dulaziz@yahoo.co.id

Al-Manähij adalah jurnal ilmiah Jurusan Syariah STAIN Purwokerto yang terbit dua kali dalam setahun. Jurnal ini memfokuskan pada kajian hukum Islam dalam berbagai sudut pandang keilmuan. Redaksi mengundang para ahli dan segenap civitas akademika untuk menulis artikel sesuai dengan tema besar jurnal ini. Artikel yang dimuat tidak selalu mencerminkam pandangan redaksi ataupun institusi lain yang terkait dengan penerbitan jurnal ini. 


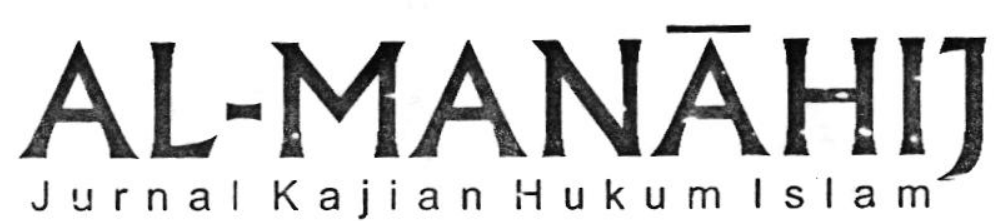

KONSEP NUSYUZ DALAM MAZHAB SYAFI'I

PERSPEKTIF KEADILAN GENDER

Dwi Meitayani 1

GRASI DALAM PERSPEKTIF HUKUM ISLAM

DAN HUKUM POSITIF INDONESIA

Imdadurrouf 23

GOOD GOVERNANCE DALAM PERSPEKTIF

HUKUM ISLAM

Arief Aulia Rachman 41

PELANGGARAN HAK KEKAYAAN INTELEKTUAL

DALAM PERSPEKTIF HUKUM ISLAM

Imam Mustofa 53

PORNOGRAFI DALAM PERSPEKTIF HUKUM ISLAM

DAN HUKUM POSITIF

Vivi Ariyanti 71

MENYOAL HUKUM MEROKOK

DALAM PERSPEKTIF HUKUM ISLAM

Muh. Mukri 91

MENUJU PENEGAKAN HUKUM

YANG LEBIH BERKEADILAN DAN RESPONSIF

Mub. Bachrul Ulum 113 


\title{
PELANGGARAN HAK KEKAYAAN INTELEKTUAL (HAKI) \\ DALAM PERSPEKTIF HUKUM ISLAM
}

\author{
Imam Mustofa*
}

\begin{abstract}
The study of violation toward intellectual property from the islamic law perspective is not much. Meanwbile it really needs protection from laws itself. This paper begin its discussion with the protection of property in Islam, the importance of fiqh for intellectual property, defining the violation law toward intellectual property and the last point is about the violation from figh perspective.
\end{abstract}

Kata kunci: $H A K I$, maslahah, al-mäl

\section{A. Pendahuluan}

Persoalan mengenai pembajakan terhadap Hak Kekayaan Intelektual (HAKI) di Indonesia sesungguhnya adalah hal baru dalam studi hukum, baik hukum positif apalagi hukum Islam. Hal ini terbukti pada munculnya banyak masalah ketika produk hukum mengenai hal tersebut di landingkan pada masyarakat. Sampai saat ini, penerapan hukum pada bidang Hak Kekayaan Intelektual masih dihadapkan pada sebuah dilema. Di satu sisi, penegakan itu adalah konsekuensi bagi Indonesia untuk sebagai salah satu anggota World Trade Organization (WTO), tapi pada sisi lain ternyata rakyat Indonesia sendiri sama sekali belum mampu untuk meninggalkan

- Penulis adalah dosen Jurusan Syariah STAIN Jurai Siwo Metro-Lampung dan alumni Pascasarjana UIN Sunan Kalijaga Jogjakarta Program Studi Hukum Islam. 
budaya pembajakan dan plagiasi. ${ }^{1}$ Masalah pembajakan dan plagiasi ini semakin menemukan celahnya ketika peralatan teknologi sudah sedemikian maju dan seolah memberikan fasilitas terhadap pelanggaraan hak milik intelektual itu dengan berbagai cara seperti pembajakan buku, film dan beberapa alat multimedia. Para opportunis memanfaatkan pelanggaran ini untuk mendapatkan keuntungan besar dengan cara yang mudah serta biaya sedikit tanpa pernah memikirkan kerugian pihak lain, seperti si pencipta dan negara. ${ }^{2}$

Meskipun keberadaan Hak atas Kekayaan intelektual pada dasarnya ada yang dihasilkan oleh dan memerlukan bentukan alam seperti indikasi geografis, namun kebanyakan HAKI lebih dialamatkan kepada "kegiatan" manusia. Lahirnya sebuah karya yang dihasilkan oleh "manusia" dengan berbekal kemampuan intelektualitasnya itu secara otomatis memunculkan hak dan kewajiban. Sederhananya, hak yang melekat pada diri si pencipta dan kewajiban yang mengikat orang lain itulah yang kemudian menuntut peran hukum untuk mengawalnya, baik peran dalam bentuk preventif maupun represif. ${ }^{3}$ Terlebih dengan adanya asumsi bahwa persinggungan antara hak dan kewajiban itu sangat mungkin terjadi.

Mengenai hal ini, Indonesia sudah patut berbangga hati karena sudah mempunyai perangkat hukum (Legal Framework) yang jelas mengenai dilindunginya Hak atas Kekayaan Intelektual setelah beberapa kali mengalami penyempurnaan, yaitu dengan disahkannya Undang-undang Nomor 29 Tahun 2000 tentang Varietas Tanaman,

${ }^{1}$ Setelah disahkannya undang-undang yang terkait dengan hak cipta, pemerintah sering melakukan sweeping dan razia terhadap produk-produk yang melanggar hak cipta. Sweeping besar-besaran yang pernah dilakukan pihak pememirintah (kepolisian) pada awal tahun 2003 adalah sweeping terbesar yang pernah dilakukan di Indonesia. Pada saat itu, sweeping dilakukan di pusat-pusat penjuaalan ved, kaset, $\mathrm{mp} 3$ dan lain semacamnya. Begitu banyak hasil bajakan yang didapatkan oleh pemerintah dan pada akhirnya semuanya dimusnahkan. Adit Ariwirawan, Ekspansi HAKI Bisa Memperparab Kemiskinan, Majalah Keadilan Lembaga Pers Mahasiswa Fakultas Hukum Universitas Islam Indonesia, Edisi II/ Tahun XXXI/2004, hal. 48.

${ }^{2}$ Syafrinaldi, "Sejarah dan Teori Perlindungan Hak Kekayaan Intelektual," dalam Jurnal Al-Manarid (Yogyakarta: Jurusan Syariah FIAI UII, 2002), hal. 2.

${ }^{3}$ Asmuni, "Hak Milik Intelektual dalam Perspektif Fiqh Islami," dalam Jurnal AlMawarid (Yogyakarta: Jurusan Syariah FIAI UII, 2002), hal.29. 
Undang-undang Nomor 30 Tahun 2000 Tentang Rahasia Dagang, Undang-undang Nomor 31 Tahun 2000 Tentang Desain Industri, Undang-undang Nomor 32 Tahun 2000 Tentang Desain Tata Letak Sirkuit Terpadu, Undang-undang Nomor 14 Tahun 2001 Tentang Paten, Undang-undang Nomor 15 Tahun 2001 Tentang Merk, dan Undang-undang Nomor 19 Tahun 2002 tentang Hak Cipta. Selain dalam bentuk Undang-undang baru produk bangsa Indonesia sendiri, diatur juga mengenai persaingan curang yang telah lama diatur dalam Kitab Undang-undang Hukum Perdata pasal 1365 tentang Perbuatan Melawan Hukum (PMH). ${ }^{4}$

Berdasarkan seperangkat regulasi di atas, terdapat dua macam hak, yaitu pertama Hak Cipta yang meliputi hak cipta dan hak-hak lain yang terkait dengan hak cipta; dan kedua, Hak Milik Perindustrian yang meliputi Paten dan Paten Sederhana, Merk, Varietas Tanaman, Desain Industri, Desain Tata Letak Sirkuit Terpadu, dan Rahasia Dagang. Inti dari pengaturan Hak atas Kekayaan Intelektual tersebut adalah untuk memberikan perlindungan terhadap pemilik atau pemegang hak sebuah karya intelektual dari tindakan-tindakan “curang" yang dilakukan orang lain.

Melihat wacana seperti itu, pembahasan mengenai HAKI ini akan sangat menarik untuk diperbincangkan. Setidaknya untuk mengetahui bagaimana pembajakan terhadap HAKI di Indonesia, dan dalam wilayah yang lebih ideal dapat memberikan solusi agar kelak Indonesia bebas dari praktek pembajakan terhadap Hak 'orang lain' dalam bidang Kekayaan Intelektual.

Untuk mewujudkan hasil yang maksimal (yaitu: bagaimana wacana pembajakan HAKI di masyarakat dan bagaimana memberantasnya), maka dalam makalah ini, penulis bermaksud memaparkan sedikit tentang bagaimana Islam memaknai dan menghargai hak seseorang, dan bagaimana pula pembajakan terhadap HAKI dalam pandangan Hukum Islam. ${ }^{5}$

\footnotetext{
${ }^{4}$ Rachmadi Usman, Hukum Hak atas Kekayaan Intelektual: Perlindungan dan Dimensi Hukumnya di Indonesia (Bandung: P. T Alumni, 2003), hal.18.

${ }^{5}$ Rakyat Indonesia adalah Religious Community yang sangat menghargai (bahkan
} 


\section{B. Perlindungan Hak dalam Islam}

Islam begitu besar perhatiannya terhadap hak milik seseorang. Banyak nașṣ yang menjelaskan bagaimana hak milik seseorang diatur oleh Islam (al Qur'an ataupun hadits) Salah satunya adalah pengaturan Islam terhadap cara seseorang memperoleh sesuatu barang agar sesuai dengan ketentuan syari'at.

Menurut Al-Ghazali, tujuan utama hukum Islam (maqäsid alshari'ab) adalah untuk memelihara lima hal pokok, yaitu agama, jiwa, akal, keturunan dan harta. ${ }^{6}$ Segala bentuk upaya untuk memelihara kelima macam ini dipandang sebagai maslahat, dan merusaknya adalah mafsadat. ${ }^{7}$

Di dalam Islam, hukum mencuri yang merupakan pelanggaran terhadap hak milik, ditegaskan di dalam Al-Qur'an: Laki-laki yang mencuri dan perempuan yang mencuri, potonglab kedua tangannya (sebagai) pembalasan bagi apa yang mereka kerjakan dan sebagai siksaan dari Allah. Allah Maha Perkasan dan Maha Bijaksana' (Q.S. Al-Mā'idah: 38 ). Nabi Muhammad SAW juga pernah bersabda tentang bahaya mencuri bagi suatu masyarakat dan ketegasan hukumnya: Demi Allab! Kalau sekiranya Fatimah binti Mubammad yang mencuri, pasti akan kupotong tangannya.' (Riwayat Bukhari)

Ketegasan aturan mengenai 'mencuri' ini menunjukkan pengakuan Islam akan hak milik, perlindungannya, dan mengatur perpindahannya secara adil. Di dalam Islam, mencuri tidak hanya dianggap merugikan orang yang dicuri secara individual, tapi juga merugikan masyarakat luas, bangsa, atau kemanusiaan itu sendiri. Bahkan secara vertical mencuri itu juga termasuk menzalimi Allah SWT. ${ }^{8}$

\footnotetext{
mensakralkan) peraturan-peraturan yang berdasarkan agama. Lihat Jaih Mubarok, "Dinamika Pemikiran Hukum Islam di Indonesia," dalam UNISLA, No. 48/XXXVI/II/2003, hal. 113-121. Sehingga dengan demikian, memasukkan peraturan-peraturan agama dalam pemerintahan sesungguhnya sebuah alternatif menumbuhkan jiwa taat hukum bagi masyarakat.

${ }^{6} \mathrm{Al}-\mathrm{Shātibi}$, al-Muvāáąăt (Beirut: Dār al-Kutub al-'Tlmiyah, 2003), II: 4.

${ }^{7}$ Amir Mu'allim, "Maqāạid al-Shari'ah: Fungsi dan Keduduknya dalam Penetapan Hukum," dalam Jurnal al-Mawarid Edisi VI Desember, 1997, hal. 2.

${ }^{8}$ Aji Hermawan, "Fiqh Hak Cipta," dalam media.isnet.org, didownload pada tanggal 16 Mei 2006.
} 
Hukuman potong tangan, yang sering dipandang sebagai tidak manusiawi bagi yang menentangnya atau sebagai hukuman yang serta merta dijalankan apa adanya bagi pendukung literalnya, pada prakteknya tidaklah dilakukan tanpa konteks. Para ahli hukum Islam sering mencontoh kisah yang terjadi dalam masa khalifah kedua Umar bin Khațāb yang tidak menghukum pencuri tapi justru mengancam akan menghukum sang pemilik barang yang dicuri.

Sedemikian lengkapnya pengaturan Islam tentang hak milik seseorang, maka tidak berlebihan jika dikatakan bahwa Pengaturan dalam Islam sesungghnya lebih lengkap dari pada hukum posititf dalam perkara hak milik. Islam mengatur bagaimana mendapatkan, memelihara, memberikan, mengalihkan hak milik dan lain sebagainya, sebagaimana pula Islam mengatur bagaimana keuntungan yang akan didapatkan seseorang dan masyarakat bila mematuhinya dan bagaimana pula sanksi yang harus ditempuh seseorang jika melanggarnya.

\section{Urgensi Fikih Hak Kekayaan Intelektual}

Undang-Undang No. 19 tahun 2002 tentang hak cipta menyebutkan bahwa hak cipta adalah hak eksklusif bagi pencipta atau penerima hak untuk mengumumkan atau memperbanyak ciptaannya atau memberikan izin untuk itu dengan tidak mengurangi pembatasanpembatasan menurut peraturan perundang-undangan yang berlaku. ${ }^{9}$

Berbeda dengan hukum positif, jika ditinjau dari hukum Islam, secara eksplisit permasalahan ini belum diatur oleh nașs, baik alQur'an maupun hadits Nabi SAW. Para ulama yang hidup pada masa täbi' al-täbi'̄in (300 tahun setelah nabi saw wafat) sering mengklasifikasikan permasalahan semacam itu dengan istilah permasalahan ijtihadiyah. Istilah ini masih populer di kalangan ulama hingga sekarang, di mana perkara-perkara yang belum diatur dalam al Qur'an secara detail dan belum pula pernah terjadi pada masa rasul saw 2003).

9 UU No. 19 tahun 2002 tentang Hak Hak Cipta (Bandung: Penerbit Citra Umbara, 
sehingga tiada pula penjelasan darinya, mak perkara itu disebut masalah ijtihadiyah. Dalam hal ini termasuk permasalahan penentuan hukum pembajakan hak cipta oleh seseorang.

Konsekuensi dari pengklasifiksian suatu perkara kepada permasalahan ijtihadiyah adalah penetapun hukum terhadap perkara itu harus dipertimbangkan dari segala bidang, dengan ketentuan hukum yang tidak statis pula, melainkan dinamis. Karena perkara ijtihadiyah yang telah ditetapkan hukumnya sekarang ini belum tentu sesuai dengan masa yang akan datang, atau bisa jadi hanya pertimbangan tempat. Artinya, bisa jadi di satu wilayah hukum terhadap sesuatu perkara berbeda dengan wilayah lain walaupun pada satu waktu itu juga.

\section{Menentukan Hukum Pelanggaran terhadap Hak Kekayaan Intelektual}

Hak milik intelektual dalam khazanah diskursus ilmu keIslaman termasuk dalam bidang mu'malah. Masalah mu'amalah dalam arti yang luas, aturan-aturan hukumnya dituangkan oleh Allah dalam bentuk garis-garis besarnya saja dan bersifat zanni (tidak pasti). Bertitik tolak dari garis-garis besar tersebut, manusia dengan potensi akal yang dianugerahkan kepadanya, diberi "kekuasaan" untuk mencari alternatif-alternatif pemecahan terhadap permasalahanpermasalahan kehidupan yang mengitarinya dan yang tidak mampu dijawab oleh nașs.

Salah satu alternatif pemecahan itu adalah munculnya konsep maqâsid al-Sharîah yang dibawa oleh al-Shātibỉ dengan magnum opusnya al-Muwâfaqât fi Uș̂ll al-Sharîah. Kandungan maqâsid alSharíab adalah kemaslahatan. Kemaslahatan itu, melalui analisis maqâsid al-Sharíah tidak hanya dilihat dalam arti teknis belaka, akan tetapi sebagai upaya dinamis untuk mengembangkan hukum dan memiliki makna filosofis dari hukum-hukum yang disyariatkan Tuhan terhadap manusia. ${ }^{10}$ Penekanan maqâsid al-Sbarîab yang dilakukan

${ }^{10}$ Asafri Jaya Bakri, Konsep Maqāṣid al-Syarīab Menurut Al-Syātibīi (Jakarta: PT. RajaGrafindo Persada, 1996), hal. 65. 
oleh al-Shātibỉ secara umum bertitik tolak dari kandungan ayat-ayat al-Qur'an yang menunjukkan bahwa hukum-hukum Tuhan mengandung kemaslahatan. ${ }^{11}$

Kaitan teori ini dengan pembahasan hak milik dalam perspektif hukum Islam adalah bahwa dalam menggali kandungan khazanah fikih Islam tentang hak milik serta menemukan ketetapan hukumnya dengan berasaskan pada konsep maqậid asy-syari’ah, karena persoalan hak milik dalam konteks modern termasuk persolan yang baru dan belum dikenal dalam ilmu keIslaman klasik, sehingga membutuhkan perangkat ijtihad yaitu teori maqâsid asy-syarîah.

Sebagaimana yang telah dikemukakan, bahwa pembajakan adalah permasalahan ijtihadiyah, permasalahan yang belum diatur dalam nașs secara eksplisit. Sehingga dalam menentukan hukumnya harus melalui penelitian ulama terhadap realitas masyarakat dan akhirnya digali hukumnya dengan menggunakan metode uṣūl fiqh sebagai alatnya.

Jika dilihat dari kasus yang terjadi di Indonesia, penentuan hukum pembajakan dapat diselesaikan dengan menggunakan metode maslaḥah mursalab ${ }^{12}$ (kepentingan umum). Karena pada dasarnya,

${ }^{11}$ Al-Shāt\}ibí, al-Muväafaqāt, II: 6-7.

12 Secara etimologi maslabah sejenis dengan kata manfa'ab, baik ukuran dan artinya. Kata mas\} lab\}ab merupakan masdar yang mengandung arti kata al-salah seperti kata manfa'ab yang mengandung arti al-naf'. Kata maslahab yang secara etimologis merupakan bentuk mufrad dari kata mașälih, bermaknan setiap sesuatu yang mengandung manfaat baik dengan cara mendatangkan sesuatu yang berguna maupun dengan menolak sesuatu yang membahayakan. Sedangkan secara terminologis mașlạab yaitu manfaat yang menjadi tujuan Shäri' untuk hamba-Nya. Manfat dalam arti suatu yang nikmat atau yang mendatangkan

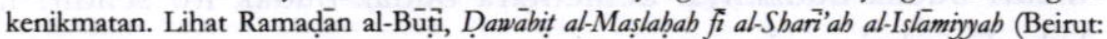
Mu'assasah al-Risalah, 1986), hal. 23; 'Izz al-Din ibn 'Abd al-Salām, Qavō'id al-Abkäm fi Mașälib al-Anām (Beirut: Dār al-Kutub al-'Ilmiyah, t.t.), hal.7-8. Istilah maslaḅab mursalab populer juga dengan istilah al-Istịlah atau al-Istidlal al-mursal. Meskipun memiliki kesamaan yang mendasar, yaitu hendak mendapatkan kemaslahatan dengan keluarnya suatu hukum dari suatu perkara tertentu, dalam pendefenisian ketiga istilah itu tidak berbeda secara esensial. Istișlặ secara bahasa adalah menuntut suatu kemaslahatan (talab al-ișläb). Sedangkan secara istilah, istịstah didefenisikan sebagai "suatu metode pengambilan hukum terhadap suatu peristiwa yang tidak memiliki dasar baik dari nas maupun ijmak ulama dengan tujuan untuk mewujudkan suatu kemaslahatan yang meyakinkan walaupun tidak ada jaminan tertentu dari syarak." Lebih lengkap lihat 'Abd al-'Aziz 'Abd al-Rahmān ibn 'Afi Rabỉ'ah,

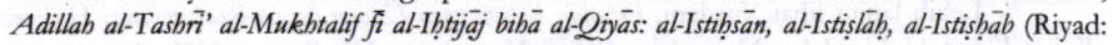
Jāmi'ah al Imām ibn al-Sa'ūd al Islāmi, . 1986), hal: 221-222. 
terbentuknya suatu hukum tiada lain kecuali bertujuan untuk mewujudkan kemashlahatan di masyarakat. Bahkan lebih liberal lagi dinyatakan bahwa nașṣ-pun pada akhirnya dapat dikesampingkan dalam rangka mewujudkan kemashlahatan itu. ${ }^{13}$

Dalam konteks sejarah, permasalahan maslaḥah mursalah juga pernah diterapkan oleh para sahabat. Misalnya, dikisahkan ketika suatu ketika terjadi paceklik, ada kasus pencurian yang dilaporkan kepada Umar untuk dihukum, tetapi Umar menolak menghukumnya, alasannya karena pada waktu itu musim paceklik dan orang itu mungkin saja terpaksa mencuri karena takut mati kelaparan. Sebaliknya Umar malah pernah mengancam, "Kalau kamu terus menerus melaporkan pencuri hartamu padahal kamu kaya, malah nanti tangan kamu yang akan saya potong, karena kamu yang menjadi sebab orang ini lapar." Dalam kisah lain disebutkan ada dua orang hamba sahaja yang mencuri dari tuannya karena tidak diberi makanan yang cukup, Umar tidak menghukumnya, tapi justru mengancam akan memotong tangan tuannya. Kisah serupa juga bisa didapati pada suatu kisah ketika beberapa budak milik Haṭib ibn Abi Balta'ah mencuri seekor unta kepunyaan tetangga, dan menyembelihnya. Umar bin Khațāb menerima pengaduan tetapi tidak segera menjatuhkan hukuman melainkan lebih dahulu bertanya kepada budak-budak itu tentang sebab-musabab mengapa sampai mencuri. Ternyata mereka benar-benar terpaksa untuk mengisi perut karena ditelantarkan oleh majikannya. Umar benar-benar marah, Haṭib segera dipanggil dan dipaksanya untuk mengganti unta yang dicuri budak-budaknya. Sementara budak-budak itu sendiri ia bebaskan dari segala tuntutan.

Ini menunjukkan bahwa dalam pelaksanaannya, hukum itu melihat konteks atau pra-kondisinya. Setiap keputusan hukum memiliki apa yang disebut sebagai 'illat (sebab, rasio-legis tentang kenapa hukum itu ditetapkan). Jadi kalau pra-kondisinya tidak terpenuhi maka hukum itu tidak bisa dijalankan.

13 Lebih lanjut lihat Yusdani, Peranan Kepentingan Umum dalam Reaktualisasi Hukum: Kajian Konsep Hukum Islam Najmuddin At-Tüfi (Yogyakarta: UII Press, . 2000), hal. 67-110. 
Dalam kaitannya dengan HAKI, terpadat dua pendapat yang saling berseberangan. Pendapat pertama, menyatakan bahwa hak milik intelektual (Intellectual Property Rights - IPR) itu harus dilindungi karena merupakan prasyarat inovasi dan pembangunan. Jika tidak dilindungi, maka orang akan malas menemukan sesuatu akibatnya inovasi terhambat, dan dalam kondisi tertentu hal ini akan menghambat laju pembangunan. Kemakmuran bangsa akan berkurang dan ini jelas merugikan. Seorang penemu juga telah menginvestasikan waktu, tenaga, uang, dan sumberdaya lainnya, sehingga sangat pantas apabila apa yang sudah dikeluarkan itu dihargai.

Bagi mereka yang sependapat dengan cara pandang seperti ini, maka pencurian terhadap hak milik intelektual sama saja dengan pencurian terhadap hak-hak lain yang dilindungi. Islam jelas melarang tindakan zălim suatu pihak terhadap pihak lain. ${ }^{14}$

Pendapat kedua, menyatakan bahwa hak milik intelektual ini justru merugikan kepentingan publik (kemaslahatan umum) karena akan semakin memperkecil hak-hak publik menjadi hak-hak private (individu atau perusahaan).

Pendapat yang menarik bisa dilihat pada tulisan George Monbiot, di Guardian, tanggal 12 Maret 2002, yang berjudul Patent Nonsense'. Dari tulisan itu kita bisa memahami bahwa rejim patent hanya menguntungkan segelintir perusahaan swasta bukan masyarakat umum. Dibuktikan pula melalui analisis sejarah ekonomi Erich Schiff, bahwa tidak benar kalau patent tidak dilindungi maka inovasi akan terhambat. Dicontohkan bahwa Swiss dan Belanda, adalah dua negara yang dalam sejarahnya tidak mau menerapkan undang-undang patent, banyak industrinya yang mencuri patent, namun justru saat itulah berkembang penemuan-penemuan dan perusahaan-perusahaan besar dari sana. Beberapa perusahaan Swiss seperti Nestle dan Ciba; juga perusahaan Belanda seperti Unilever dan Philips, adalah perusahaan yang tumbuh karena 'berkah' mencuri patent atau tidak adanya aturan patent itu. Namun perusahaan-

14 Hermawan, "Fiqh.," hal. 3 
perusahaan itu sekarang berbalik melakukan lobby-lobby untuk memperketat aturan patent.

Tarik menarik di antara dua kubu inilah, paling tidak, yang bisa memberi gambaran tentang perlunya kejelian dan kehati-hatian untuk mengambil keputusan mengenai HAKI. Kalau dikembalikan kepada hukum Islam maka kita bisa memakai kaidah: "idza ta'äradat al mașlahatāni quddima a'zamu bumā", artinya apabila terjadi dua maslahat yang bertentangan, maka ambillah yang memiliki kemaslahatan yang lebih besar.

\section{E. Pelanggaran Hak Kekayaan Intelektual dalam Perspektif Fikih Islam}

Fiqh Islam memasukkan HAKI dalam al-mâl, sehingga keberadaan undang-undangnya sebagai bentuk perlindungan terhadap karya secara umum tidak bertentangan dengan syari'ah. Hak seorang dalam Hak Milik Intelektual (selanjutnya ditulis HAMI) adalah berupa ḥaqq 'ayni mâli gbayru mujarrad (hak kehartabendaan yang permanen). ${ }^{15}$ Disebut dengan ḅaqq 'ayni ${ }^{76}$ karena seseorang mempunyai kekuasaan penuh untuk menggunakan dan mengembangkan haknya itu.

Sedangkan dinamakan dengan ḥaqq mâlı karena obyek dari HAMI adalah al-mâl. Sedangkan penamaannya disebut dengan haqq gairu mujarrad (ḅaqq mutaqarrar) karena haqq mujarrad tidak dapat berubah walaupun dicabut atau digugurkan oleh pemiliknya. Dengan kata lain ḅaqq mujarrad $^{17}$ tidak meninggalkan bekas apabila digugurkan oleh pemiliknya. Berbeda dengan HAMI sebagai ḥaqq mutaqarrar yang apabila digugurkan atau dimaafkan meninggalkan bekas terhadap

\footnotetext{
${ }^{15}$ Asmuni, "Hak Milik," hal. 30-31.

${ }^{16}$ Haqq 'ayni adalah hak seseorang yang ditetapkan syara' terhadap suatu benda, sehingga ia memiliki kekuasaan penuh untuk menggunakan dan mengembangkan haknya. Lihat Tim Redaksi, Ensiklopedi Hukum Islam (Jakarta: PT. Ichtiar Baru Van Hoeve, 2000), II: 488.

${ }^{17}$ Sedangkan yang dimaksud dengan baqq mujarrad adalah hak murni yang tidak meninggalkan bekas (pengaruh) apabila digugurkan melalui perdamaian atau pemaafan. Lihat Ibrāhìm Fãḍil al-Dabbo, Ḍamān al-Manâfi': Dirâsab Muqâranah fí al-Figh al-Islâmi wa alQânûn al-Madanì (Beirut: Dār al 'Ammār, 2000), hal. 320.
} 
orang yang dimaafkan. Misalnya apabila seseorang meninggalkan ḅaqq mâli atas karyanya di depan penerbit, maka karya itu boleh dimanfaatkan oleh siapa saja padahal sebelumnya hanya bisa dapat dimanfaatkan oleh pemiliknya saja. Ketika ḅaqq mâlî suatu karya digugurkan oleh pemiliknya, maka status hukumnya pun berubah. ${ }^{18}$

Sejalan dengan pendapat di atas, Az-Zarqā' memasukkan HAMI yang ia sebut dengan istilah al-buqûq al-adabiyyab juga ke dalam hak material (al-buqûq al-mâliyyab). Kedudukan al-buqûq al-adabiyyab ini sejajar dengan al-ḥaqq al-syakhsh dan al-ḥaqq al-'aynî. Lebih lanjut ia menyebutkan bahwa HAMI meliputi hak cipta, hak pengarang, dan hak yang berkaitan dengan penemuan lainnya dalam bidang seni maupun teknologi. Akan tetapi Az-Zarqa' lebih cenderung menyebut HAMI dengan istilah haqqq al-ibtikâr karena sekupnya lebih luas dari pada al-buqûq al-adabiyyah. ${ }^{19}$ Selanjutnya, Muhammad Usman Syabir lebih menspesifikkan HAMI sebagai ḥuqûq ma'nawiyyah yang merupakan bagian dari buqûq mâliyyah.

Dengan demikian, kedudukan HAMI dalam hukum Islam (figh) adalah sah, karena sudah meliputi beberapa hak yang telah dikonsepsikan oleh para fukaha sebelumnya. Di antara hak-hak itu antara lain ḥaqq'aynì mâlî ghayru mujarrad, al-ḥuqûq al-adabiyyah, ḅuqûq ma'nawiyyah, dan ḅuqûq al-ibtikâr.

Kajian soal HAKI dalam Islam juga telah dilakukan oleh Majma' al-Fiqh al-Islāmi. Dalam hal ini lembaga ini mengeluarkan keputusan Nomor 43 (5/5) Mu'tamar V tahun 1409 H/1988 M tentang huqûuq ma'nawiyyab:

Pertama. Nama dagang, alamat dan mereknya, serta hasil ciptaan (karang-mengarang) dan hasil kreasi adalah hakhak khusus yang dimiliki oleh pemiliknya, yang dalam abad

${ }^{18}$ Asmuni, "Hak Milik,", hal. 35.

${ }^{19}$ Menurutnya, HAMI merupakan persoalan baru yang lahir sebagai akibat dari sistem kehidupan modern dalam berbagai bidang, terutama ekonomi dan kebudayaan. Tujuan dari HAMI adalah untuk memberi motivasi kepada umat Islam untuk melahirkan karya dan penemuan-penemuan baru. Lihat Musțafa Aḥmad al-Zarqä', al-Figh al-Islamìi $\bar{f}$ CEaubih alJadîd (Beirut: Dār al-Fikr, t.t), III: 21. 
moderen hak-hak seperti itu mempunyai nilai ekonomis yang diakui orang sebagai kekayaan. Oleh karena itu, hakhak seperti itu tidak boleh dilanggar.

Kedua. Pemilik hak-hak non-material seperti nama dagang, alamat dan mereknya, dan hak cipta mempunyai kewenangan terhadap haknya itu, dan bisa ditransaksikan dengan sejumlah uang dengan syarat terhindar dari berbagai ketidakpastian dan tipuan, seperti halnya dengan kewenangan seseorang terhadap hak-hak yang bersifat material.

Ketiga. Hak cipta, karang-mengarang dan hak cipta lainnya dilindungi oleh syara'. Pemiliknya mempunyai kewenangan terhadapnya dan tidak boleh dilanggar.

Majelis Ulama Indonesia (MUI), lembaga yang menjadi wadah atau majelis yang menghimpun para ulama, zuama dan cendekiawan muslim Indonesia untuk menyatukan gerak dan langkah-langkah umat Islam Indonesia dalam mewujudkan cita-cita bersama. Menurut MUI, perlindunngan Hak Cipta tidak bertentangan dengan syariat Islam. ${ }^{20}$

MUI Bahkan mengeluarkan fatwa khusus berkaitan dengan perlindungan HAKI, yaitu fatwa MUI No. 1 Tahun 2003 tentang Hak Cipta. Pendapat MUI menggolongkan Hak Cipta sebagai barang berharga yang boleh dimanfaatkan secara syara' (hukum Islam), mengutip pendapat cendekiawan muslim Beirut, Fatḥi al-Durayni dalam kitabnya Haqq al-Ibtikēr $\overline{f i}$ al-Fiqh al-Islämi al-Muqäran.

Mayoritas ulama dari kalangan Mazhab Maliki, Syafi'i, dan Hambali berpendapat babwa hak cipta atas ciptaan yang orisinal dan manfaat tergolong harta berharga, sebagaimana benda jika boleh dimanfaatkean secara syara' (bukum Islam). ${ }^{21}$

${ }^{20}$ Hukum Online, "Mengkaji Hak Kekayaan Intelektual dari Kacamata Hukum Islam," bukumonline.com, tertanggal 25 Januari 2003. Didownload tanggal 16 Mei 2006.

${ }^{21}$ Fathịi al-Durayni, Haqq al-Ibtikär fi al-Figh al-Istamì al-Muqäran, (Beirut: Dār al-Fikr al-Mu'āṣir, 1984), IV: 20. 
Selain fatwa No. 1 tahun 2003 tersebut, pada tahun 2005, MUI juga meneluarkan fatwa tenteng Perlindungan Hak Kekayaan Intelektual (HAKI). bagian kedua fatwa ini menetapkan: pertama, Dalam hukum Islam, HAKI dipandang sebagai salah satu ḅuqûq māliyyah (hak kekayaan) yang mendapat perlindungan hukum (mashūn) sebagaimana mäl (kekayaan). Kedua, HAKI yang mendapat perlindungan hukum Islam sebagaimana dimaksud angka 1 tersebut adalah HAKI yang tidak bertentangan dengan hukum Islam. Ketiga, HAKI dapat dijadikan obyek akad (al-ma'qüd 'alayb), baik akad mu'awadab (pertukaran, komersial), maupun akad tabarru'at (nonkomersial), serta dapat diwakafkan dan diwariskan. Keempat, Setiap bentuk pelanggaran terhadap HAKI, termasuk namun tidak terbatas pada menggunakan, mengungkapkan, mem-buat, memakai, menjual, mengimpor, meng-ekspor, mengedarkan, menyerahkan, menyediakan, mengumumkan, memperbanyak, menjiplak, memalsu, membajak HAKI milik orang lain secara tanpa hak merupakan kezaliman dan hukumnya adalah haram.

Berkenaan dengan hak kepengarangan (ḅaqq al-ta'liff), salah satunya hak cipta, perlu dipertimbangkan pendapat Wahbah alZuhayli. Ilmuwan muslim ini berpendapat bahwa hak kepengarangan dilindungi oleh hukum Islam. Karenanya, mencetak ulang atau mengkopi buku tanpa izin merupakan pelanggaran atau kejahatan terhadap hak pengarang. ${ }^{22}$

Berdasarkan alasan tersebut menurut MUI pelanggaran hak cipta hukumnya adalah haram. "Pembajakan bukan saja termasuk perbuatan maksiat, tapi juga merupakan perbuatan zalim. Memanfaatkan hak orang lain, sama halnya dengan mencuri." ${ }^{23}$

Menurut Ma'ruf Amin, maraknya pelanggaran terhadap HAKI, khususnya tindak pembajakan, mematikan kreativitas seniman dalam berkarya. Ma'ruf Amin juga mengatakan bahwa

${ }^{22}$ Wahbah al-Zuhayfi, Al-Figh al-Istämi wa Adillatub (Beirut: Dār al-Fikr al-Mu’āșir, 1998), IV: 2862.

${ }^{23} \mathrm{Hal}$ ini ditegaskan oleh Ketua Umum Komisi Fatwa MUI, KH Ma'ruf Amin, saat dikeluarkannya fatwa MUI tentang pembajakan.

Al-Manāhij, Vol. 4 No.1, Januari - Juni 2010 
fatwa ini bukan segala-galanya, tapi merupakan sebuah pendekatan moral. ${ }^{24}$

Berbagai pernyataan ulama dan keputusan lembaga di atas merupakan bentuk nyata perhatian dan upaya perlindungan mereka terhadap hak kekayaan intelektual. Pendapat-pendapat di atas pada dasarnya adalah fikih hak kekayaan intelektual yang masih berserak. Oleh karena itu perlu rumusan khusus konstruksi fikih hak kekayaan intelektual sebagai jawaban hukum Islam terhadap perkembangan hak di era modern.

\section{F. Penutup}

Realita pembajakan di Indonesia sudah masuk dalam kategori parah. Seakan-akan aktifitas ini telah menjadi budaya di negara ini. Maka, wajar jika pihak pemerintah sangat kewalahan memberantas 'kegiatan masyarakat' ini. Tapi, apapun ceritanya, pembajakan sesunggunya akan menimbulkan kerugian yang sangat luar biasa di masyarakat. Tidak terbatas hanya pada kerugian finansial saja, melainkan kerugian dalam bidang etos kerja dan pemikiran yang inovatif juga akan dirasakan. Sebaliknya, suatu negara yang bebas dari pembajakan akan lebih kreatif mengeluarkan ide-ide baru yang cemerlang sehingga dapat memberikan kontribusi keilmuan yang baik bagi rakyat dan negaranya.

Peran hukum Islam juga sangat diperlukan dalam hal ini, untuk meredam aktivitas pembajakan sekaligus meningkatkan pola pikir masyarakat sudah seharusnya hukum Islam melalui para pakarnya, berperan memberikan kontribusi kepada negara, atau setidaknya hanya memberikan petunjuk kepada umat, mana jalan yang benar untuk selanjutnya diterapkan, dan mana yang salah untuk selanjutnya ditinggalkan.

Meskipun dari pembahasan di atas dapat diketahui bahwa pembajakan HAKI dalam fikih Islam adalah haram, namun demikian hukum Islam belum megatur secara detail tentang praktek

${ }^{24}$ Ibid. 
pembajakan ini. Oleh karena itu menjadi tugas kita semua untuk memberikan penjelasan kepada masyarakat bagaimana Islam memandang praktek pembajakan terhadap HAKI. Dengan demikian, akan lebih nyata bahwa Islam pada dasarnya memang komprehensif, termasuk mengatur hukum kekayaan intelektual secara detail. 


\section{DAFTAR PUSTAKA}

'Abd al-Salām, 'Izz al-Din. Qawā'id al-Aḅkām fi Mașālị̣ al-Anām.

Beirut: Dār al-Kutub al-'Ilmiyah, t.t.

Al-Dabbo, Ibrāhim Fādil. Damān al-Manâfi': Dirâsab Muqâranah fi al-Figh al-Islâmī wa al-Qânûn al-Madañ. Beirut: Dār al 'Ammār, 1997.

Al-Būṭi, Sa'id Ramāḍan. Dawābiṭ al-Mașlaḥah fī al-Sharī'ab alIslämiyyah. Beirut: Mu'assasah al-Risālah, 1986.

Al-Durayni, Fathị. Haqq al-Ibtikär fî al-Fiqh al-Islämi al-Muqäran. Beirut: Dār al-Fikr al-Mu’āsir, 1984.

Ali Rabī'ah, Abdul Aziz Abdul Rahmān bin, Adillatu al-Tasyrī': alMukbtalif fi al-Ibtijāj bibā al Qiyass, al Istibsān, al Istișlāh, al Istịshāb, Jai'ah al Imām bin Su'ūd al Islami. tanpa penerbit, 1984.

Al-Shātịibi. Al-Muwāaqaāat. Beirut: Dār al-Kutub al-'Ilmiyah, 2003.

Al-Zuhayli, Wahbah. Al-Fiqh al-Istamì wa Adillatuh, 9 jilid. Beirut: Dār al-Fikr al-Mu'āṣir, 1998.

Ariwirawan, Adit. "Ekspansi HAKI Bisa Memperparah Kemiskinan," dalam Majalab Keadilan. Lembaga Pers Mahasiswa Fakultas Hukum Universitas Islam Indonesia, Edisi II/Tahun XXXI/2004.

Bakri, Asafri Jaya. Konsep Maqāsid al-Shari'ah Menurut al-Shätibìi. Jakarta: PT. RajaGrafindo Persada, 1996.

Gautama, Sudargo. Segi-Segi Hak Milik Intelektual. Bandung: Fresco, 1990.

Hermawan, Aji. "Fiqh Hak Cipta," dalam media.isnet.org. Diakses pada tanggal 16 Mei 2006.

"Mengkaji Hak Kekayaan Intelektual dari Kacamata Hukum Islam," dalam Hukum Online, tertanggal 25 Januari 2003. Diakses pada tanggal 16 Mei 2006. 
Asmuni. "Hak Milik Intelektual dalam Perspektif Fiqh Islami," dalam Jurnal Al-Mawarid Edisi IX. Yogyakarta: Jurusan Syariah FIAI UII, 2002.

Mu'allim, Amir. "Maqāṣid al-Sharỉ'ah: Fungsi dan Kedudukannya dalam Penetapan Hukum," dalam Jurnal al-Mawarid Edisi VI Desember, 1997.

Mubarok, Jaih. "Dinamika Pemikiran Hukum Islam di Indonesia," dalam UNISLA: Jurnal Ilmu-Ilmu Sosial No. 48/XXXVI/II/ 2003.

Muhammad, Abdulkadir. Kajian Hukum Ekonomi Hak Kekayaan Intelektual. Bandung: Citra Aditya Bakti, 2001.

Syafrinaldi. Sejarah dan Teori Perlindungan Hak Kekayaan Intelektual, dalam Jurnal Al Mawarid Edisi IX. Yogyakarta: Jurusan Syariah FIAI UII, 2002.

Tim Redaksi. Ensiklopedi Hukum Islam, 6 jilid. Jakarta: PT. Ichtiar Baru Van Hoeve, 1997.

Usman, Rachmadi. Hukum Hak atas Kekayaan Intelektual: Perlindungan dan Dimensi Hukumnya Di Indonesia. Bandung: P.T. Alumni, 2003.

UU No. 19 tabun 2002 tentang Hak Hak Cipta. Bandung: Penerbit Citra Umbara Februari 2003.

Yusdani. Peranan Kepentingan Umum Dalam Reaktualisasi Hukum: Kajian Konsep Hukum Islam Najamuddin At Tufi. Yogyakarta: UII Press, 2000.

Al-Zarqā', Musțāfa Aḥmad. Al-Fiqh al-Islämi fí Śawbib al-Jadîd, 3 jilid. Beirut: Dār al Fikr, t.t. 
